\title{
ON THE BOUNDARY OF CONVEXITY OF UNIVALENT FUNCTIONS CLASS IN HALF-PLANE
}

\section{J. KIRJACKIS}

Vilnius Gediminas Technical University

Sauletekio av. 11, Vilnius, Lithuania

E-mail: ekira@post.omnitel.net

Received October14, 2001; revised January 20, 2002

\begin{abstract}
In this article we establish the maximum radius of the disc which any univalent in the half-plane function maps onto a convex domain.
\end{abstract}

\section{INTRODUCTION}

Let $K(D)$ be a certain subclass of class of analytical in the domain $D$ functions. Maximal number $R\left(z_{0}\right)$ for which any function of $K(D)$ maps disc with center in the point $z_{0} \in D$ and radius $R\left(z_{0}\right)$ onto a convex domain is called the boundary of convexity of class $K(D)$ in the point $z_{0}$. The radius problem was raised for various subclasses of analytic in the unit disc functions (see, for instance [3] - [6]). It is known [1], that for class $S$ of functions, which are univalent and normalized $\left(f(0)=0, f^{\prime}(0)=1\right)$ in the unit disc, the boundary of convexity with respect to point $z_{0}$ is the number $r\left(z_{0}\right)=2-\sqrt{3+z_{0}^{2}}$. Our goal is to establish the boundary of convexity of class of functions which are univalent and normalized in the half-plane.

\section{RESULTS}

By $S$ we denote a class of functions $g(\omega)=\omega+b_{2} \omega^{2}+\cdots$ being univalent and normalized in the unit disc $E=\{|\omega|<1\}$. Let $U$ denote a class of functions of the type

$$
F(z)=z-1+a_{2}(z-1)^{2}+\cdots
$$


univalent in half-plane $\Pi=\{\operatorname{Re} z>0\}$. By $C(a, \rho)$ we denote an open disc with a center in point $a \in C$ and with radius $\rho$.

Main result of the present paper is contained in the following theorem.

Theorem 2.1. (On the boundary of convexity of class $U$.) Let $z_{0}$ be a fixed point from half-plane $\Pi$. If $0<r \leq \frac{1}{2} \operatorname{Re} z_{0}$, then any function $F(z) \in U$ maps disc $C\left(z_{0}, r\right)$ onto convex domain. If $\frac{1}{2} \operatorname{Re} z_{0}<r<\operatorname{Re} z_{0}$, then in class $U$ there exists a function mapping disc $C\left(z_{0}, r\right)$ onto non-convex domain.

To prove the theorem we need to have an auxiliary lemma.

Lemma 2.1. Let $r<z_{0}$. Then function $\omega=(z-1) /(z+1)$ maps $C\left(z_{0}, r\right)$ onto $C\left(\omega_{0}, R\right)$, ( and function $z=(1+\omega) /(1-\omega)$ consequently, $C\left(\omega_{0}, R\right)$ onto $\left.C\left(z_{0}, r\right)\right)$, where

$$
\omega_{0}=\frac{z_{0}^{2}-r^{2}-1}{\left(z_{0}+1\right)^{2}-r^{2}}, \quad R=\frac{2 r}{\left(z_{0}+1\right)^{2}-r^{2}} .
$$

Proof of this Lemma follows from circular property of linear-fractional mapping and principle of symmetry for analytic functions.

Proof of the theorem 2.1. First, let us consider a case when point $z_{0} \in \Pi$ lies on a real positive semi-axis. Let $z_{0}$ and $r$ be connected by a relation $z_{0}=$ $k r, k>1$. Note that in this case conditions $0<r \leq z_{0} / 2$ and $z_{0} / 2<r<z_{0}$ are equivalent to conditions $k \geq 2$ and $1<k<2$ respectively. Let us assume that on condition that $0<r \leq z_{0} / 2$ (i.e. when $k \geq 2$ ) in class $U$ function $F_{0}(z)$ has been found which maps disc $C\left(z_{0}, r\right) \subset \Pi$ on some non-convex domain $D$. Then function

$$
g_{0}(\omega)=\frac{1}{2} F_{0}\left(\frac{1+\omega}{1-\omega}\right)
$$

belonging to class $S$ would map disc $C\left(\omega_{0}, R\right)$, where $\omega_{0}$ and $R$ are found from (2.1), onto non-convex domain $\frac{1}{2} D$. In fact, it is obvious that $r<z_{0}$ and by lemma function

$$
z=\frac{1+\omega}{1-\omega}
$$

maps $C\left(\omega_{0}, R\right)$ onto $C\left(z_{0}, r\right)$.

For any $r>0$ and $k>0$ the following identity takes place

$$
R^{2}-4 R+1-\omega_{0}^{2}=\frac{4 r(k-2)}{(k r+1)^{2}-r^{2}}
$$


where $R$ and $\omega_{0}$ are defined from relations (2.1) when $z_{0}=k r$. If $k \geq 2$ then for any $r>0$ we have $R^{2}-4 R+1-\omega_{0}^{2} \geq 0$. In this case any function of class $S$ (including also $\left.g_{0}(\omega)\right)$ should map $C\left(\omega_{0}, R\right)$ onto convex domain [1]. Obtained contradiction shows that on condition that $0<r \leq z_{0} / 2$ the assumption on existence in class $U$ a function mapping disc $C\left(z_{0}, r\right)$ onto non-convex domain was incorrect.

If $1<k<2$ (i.e. $z_{0} / 2<r<z_{0}$ ), then from (2.2) we receive

$$
R=2-\sqrt{3+\omega_{0}^{2}}+\varepsilon, \quad \varepsilon>0 .
$$

Since it is obvious that $C\left(\omega_{0}, R\right) \subset E$, then $R<1-\left|\omega_{0}\right|$ and, hence

$$
0<\varepsilon<1-\left|\omega_{0}\right|-\left(2-\sqrt{3+\omega_{0}^{2}}\right) .
$$

Thus [1] in class $S$ one can find such a function $g_{1}(\omega)$, which maps $C\left(\omega_{0}, R\right)$ onto non-convex domain $G$. But then, function

$$
F_{1}(z)=2 g_{1}\left(\frac{z-1}{z+1}\right)
$$

belonging to class $U$ will map disc $C\left(z_{0}, r\right)$ onto non-convex domain $2 G$, since according to lemma, function

$$
\omega=\frac{z-1}{z+1}
$$

maps $C\left(z_{0}, r\right)$ onto $C\left(\omega_{0}, R\right)$. So, in case when $z_{0}$ lies on the positive real semi-axis, this theorem is proved.

Now let $z_{0}=x_{0}+\mathrm{i} y_{0}$ be an arbitrary point of $\Pi$ and $0<r \leq \frac{1}{2} \operatorname{Re} z_{0}$. As it was proved, any function of $U$ maps disc $C\left(x_{0}, r\right)$ onto convex domain. If there was function $F_{2}(z)$ in $U$ mapping $C\left(z_{0}, r\right)$ onto non-convex domain, then function

$$
F_{3}(z)=\frac{F_{2}\left(z+\mathrm{i} y_{0}\right)-F_{2}\left(1+\mathrm{i} y_{0}\right)}{F_{2}^{\prime}\left(1+\mathrm{i} y_{0}\right)},
$$

also belonging to class $u\left(F_{2}^{\prime}\left(1+\mathrm{i} y_{0}\right) \neq 0\right.$, since $\left.F_{2}(z) \in U[2]\right)$, would map disc $C\left(x_{0}, r\right)$ onto non-convex domain, that is impossible. The first part of theorem, in any case, is proved. Similarly, if $z_{0}=x_{0}+\mathrm{i} y_{0} \in \Pi$ and $\frac{1}{2} \operatorname{Re} z_{0}<$ $r<\operatorname{Re} z_{0}$, on the basis of the proved, in class $U$ there exists function $F_{4}(z)$, mapping $C\left(x_{0}, r\right)$ onto non-convex domain. Then function

$$
F_{5}(z)=\frac{F_{4}\left(z-\mathrm{i} y_{0}\right)-F_{4}\left(1-\mathrm{i} y_{0}\right)}{F_{4}^{\prime}\left(1-\mathrm{i} y_{0}\right)},
$$

belonging to $U$ will map $C\left(z_{o}, r\right)$ onto non-convex domain. Theorem is fully proved. 


\section{CONCLUSION}

In the present paper we have established, that the boundary of convexity with respect to point $z_{0}$ of the class $U$ of functions, which are univalent and normalized $\left(F(1)=0, F^{\prime}(1)=1\right)$ in the half-plane $\Pi=\{\operatorname{Re} z>0\}$ is the

number $R\left(z_{0}\right)=\frac{1}{2} \operatorname{Re} z_{0}$, that looks surprisingly simple.

\section{REFERENCES}

[1] I.A. Aleksandrov. On the boundary of convexity and starlikeness for functions which are univalent and regular in the disc. $D A N, \mathbf{1 6}(6), 903-905,1957$. (in Russian)

[2] A.V. Bicadze. Elements of theory of analytic functions of complex variable. Moskva: Nauka, 1972. (in Russian)

[3] A. Gangadharan, V. Ravichandran and T.N. Shanmugam. Radii ov convexitu and starlikeness for some classes of analytic functions. J. Math. Anal. Appl., 211(1), $301-$ 313, 1997.

[4] L. Koczan. Radii of convexity in some directions for the class typically real functions. Zesz. Nauk. Politech. Rzesz., Math., 162(21), 57 - 62, 1997.

[5] A. Lecko and M. Lecko. On a radius problem in some subclasses of univalent functions. ii. Zesz. Nauk. Politech. Rzesz., Math., 154(20), 73-87, 1996.

[6] M. Nunokawa and D.K. Thomas. On convex and starlike functions in a sector. Aust. Math. Soc., Ser. A, 60(3), 363-368, 1996.

\section{Apie vienalapių pusplokštumėje funkcijų klasès iškilumo spindulị}

\section{J. Kirjackis}

Straipsnyje nustatomas maksimalus spindulys skritulio, kuri visos vienalapès ir normuotos pusplokštumëje funkcijos atvaizduoja i iškilają sritį. Tegul $K(D)$ - poklase analizinių srityje $D$ funkcijų klasès. Maksimalų skaičių $R\left(z_{0}\right)$ toki, kad visos funkcijos iš $K(D)$ atvaizduoja skrituli su centru taške $z_{0}$ ir spinduliu $R\left(z_{0}\right)$ i iškiliają sritị, vadinsime klasės $K(D)$ iškilumo spinduliu taško $z_{0}$ atžvilgiu. Iškilumo spindulio problema buvo keliama įvairioms analiziniu funkciju vienetiniame skritulyje poklasems. Šiame straipsnyje nustatomas vienalapiu ir normuotu $\left(F(1)=0, F^{\prime}(1)=1\right)$ pusplokštumèje $\Pi=\{\operatorname{Re} z>0\}$ funkcijų klasès iškilumo spindulys taško $z_{0}$ atžvilgiu. 